\title{
The Influence of Organizational Culture on Employee
}

\section{Performance}

\section{Yeti Kuswati}

Lecturer in Public Administration - Majalengka University, Indonesia yeti.kuswati@yahoo.co.id

\begin{abstract}
This study was motivated by the insignificant performance of employees at Municipal Waterworks (Perusahaan Daerah Air Minum, PDAM) in Majalengka Regency office. Their performance was considered to be insignificant due to the following indicators: (1) some employees were less responsible resulting poor performance in carrying out the task; (2) some employees lack discipline in carrying out tasks such as coming and leaving work not following the applicable regulations; (3) some employees carried out their tasks not following the applicable guidelines (resulting poor quality of work); (4) There were delays in reporting by employees. This study used descriptive and survey methods by processing and analyzing quantitative data through a parametric statistical approach. The calculation was conducted using the SPSS version 19 program. The parameters used were variable $X$ which was organizational culture and variable $Y$ which was employee performance. According to Robin, organizational culture includes innovation and risk placement, clear attention, outcome orientation, people orientation, team orientation, aggressiveness, and stability. Meanwhile, according to Moeherionon, employee performance includes effectiveness, efficiency, quality, timeliness, productivity, and safety. After analyzing the data and testing the hypothesis, the results indicated that the organizational culture in Majalengka PDAM office was categorized well with the respondents' response of 3.45 and a standard deviation of 0.574. Meanwhile, the employee performance reached a good category with a respondents' response of 3.49 and a standard deviation of 0.705 . The correlation coefficient $(r)$ between variable $X$ and $Y$ was 0.828 indicating the influence of organizational culture on service quality by $68.5 \%$. Moreover, the results of the $t$-test (significant level) obtained a $t$-value of 15.683 with a $t$-table of 1.661. Thus, t-arithmetic was greater than the t-table. Therefore, $\mathrm{HO}$ was rejected and $\mathrm{HI}$ was accepted. In other words, there was a positive and significant influence between organizational cultures $(X)$ on employee performance $(Y)$.
\end{abstract}

Keywords

public senvices organizational culture; employee performance

\section{Introduction}

Municipal Waterworks or so-called Perusahaan Daerah Air Minum, hereinafter abbreviated as PDAM, carry out the main task of carrying out clean water management and services to improve the welfare of the community under the Law No. 32 of 2004, concerning Local Government. That Act implies that local governments are obliged to be professional in carrying out the government effectively and efficiently as well as be able to face the challenges of environmental change. Local government as a provider of public services 
always demands its ability to improve the quality of services, to set service standards that have dimensions to maintain the quality of life, protect the safety and welfare of the people. In carrying out public services, Local government is required to change the mindset and performance of its organizers, adjusted to the purpose of providing regional autonomy by providing and improving services that satisfy the community. Community satisfaction will be achieved using quality services (My, Thi, and Hanh 2020; Yadav and Rai 2015).

For the realization of good governance, in carrying out public services, the Local Government has to provide broad opportunities for citizens and the public by giving access to public services, based on the principles of equality, transparency, accountability, justice, and legal certainty. The demand for public services goals in providing satisfaction to customers (the community) is a challenge for Municipal Waterworks (PDAM) in continuing to strive in the realization of the mission and function in providing optimal services. Thus, the drinking water systems have to be managed well and meet the technical and economic rules under predetermined criteria.

Various complaints and public dissatisfaction with public services indicate the urgency of an expectation that changes in the performance of government employees in a better way. To support this change, it is necessary to have a standard reference imposed by an organization. The standard reference is the organizational culture that systematically guides employees to increase their work commitment to the organization. Organizational culture can function as a binding demand for its members because it can be formally formulated in various rules and regulations of the organizations. Thus, individuals within the organization will indirectly be bound to form attitudes and behaviors following the organizational vision, mission, and strategies. Organizational culture may influence organizational performance (Ahmed and Shafiq 2014; Ehtesham, Muhammad, and Muhammad 2011; Ting 2011) because culture can form capable individuals and have high integrity and shape in their behavior at work (Joko Suwaryo, Heny K. Daryanto 2015). In addition to producing qualified human resources, the success of the organization also depends on its culture. A strong organizational culture is expected to strengthen individuals within the organization to form attitudes and behaviors that can produce a maximum performance to improve the quality of performance through organizational culture (Faizal and Isa 2016; Nanda Novziransyah 2017; Sagita 2018).

Likewise, the PDAM office in Majalengka Regency needs organizational culture to improve employee performance. Organizational culture can encourage PDAM employees to be enthusiastic and discipline in carrying out organizational work. The organizational culture of the Majalengka Regency PDAM office is expected to inspire all employees and provide the distinctive character of the Majalengka Regency PDAM office and be an embodiment to attract public confidence in employee performance. Based on the description above, the researcher interested in conducting a study and writing a thesis entitled "The influence of organizational culture on employee performance at the PDAM office in Majalengka Regency".

\section{Research Method}

This study employed descriptive and survey methods where the research carried out by directly taking data that occurs during the study to find out, study, and describe the influence of variable, organizational culture, on employee performance at PDAM office in Majalengka Regency by processing and analyzing quantitative data through a parametric statistical 
approach. This study involved two variables, namely the independent variable (variable $\mathrm{X}$ ) and the dependent variable (variable $\mathrm{Y}$ ). The independent variable (variable $\mathrm{X}$ ) was an organizational culture. Meanwhile, the dependent variable (variable Y) was the employee performance at the PDAM office in Majalengka Regency. The population of this study was 162 employees at the Majalengka Regency PDAM office. The samples were 115 employees taken using Solvin formula and random sampling technique. After analyzing descriptive data, the testing hypothesis was conducted through a quantitative approach. The hypothesis was tested using the Pearson product-moment (r) correlation technique to test the correlation and followed by simple regression analysis.

\section{Discussion}

The description of the research variables was intended to obtain an empirical picture of the research variables. Analysis of the description of research variables was conducted based on concepts and theories that had been described in the literature review.

Table 1. The organizational culture variable descriptions

\begin{tabular}{|l|c|c|c|}
\hline \multicolumn{1}{|c|}{ Dimension } & Mean & St-dev & Description \\
\hline Innovation and risk placement & 3.66 & 0.561 & Good \\
\hline Attention to task details & 3.37 & 0.521 & Quite Good \\
\hline Outcome orientation & 3.34 & 0.535 & Quite Good \\
\hline People orientation & 3.40 & 0.657 & Good \\
\hline Team orientation & 3.65 & 0.562 & Good \\
\hline Aggressiveness & 3.45 & 0.601 & Good \\
\hline Stability & 3.30 & 0.581 & Quite Good \\
\hline Organizational culture variable & 3.45 & 0.574 & Good \\
\hline
\end{tabular}

Source: research data analyzed

Table 1 illustrated that the organizational culture variable was formed by seven dimensions, namely innovation and risk placement, attention to task details, outcome orientation, people orientation, team orientation, aggressiveness, and stability. The organizational culture obtained a good category based on the cumulative average value obtained of 3.45. However, based on the analysis of the dimensions, the average value of the dimensions was ranged from 3.30 to 3.66. Thus, respondents' answers ranged from quite good to good category. Table 1 showed that the stability dimension had the lowest value of 3.30 with quite good criteria. This indicated that a stability dimension with indicators of the ability to create challenges and the working conditions system had not been fully implemented optimally. Meanwhile, employee performance variables were formed by six dimensions, namely effectiveness, efficiency, quality, timeliness, productivity, and safety. The analysis of employee performance was described in the following table:

Table 2. Employee performance variable descriptions

\begin{tabular}{|l|c|c|c|}
\hline \multicolumn{1}{|c|}{ Dimension } & Mean & St-dev & Description \\
\hline Effectiveness & 3.68 & 0.681 & Good \\
\hline Efficiency & 3.65 & 0.729 & Good \\
\hline Quality & 3.37 & 0.653 & Quite Good \\
\hline
\end{tabular}




\begin{tabular}{|l|c|c|c|}
\hline \multicolumn{1}{|c|}{ Dimension } & Mean & St-dev & Description \\
\hline Timeliness & 3.31 & 0.633 & Quite Good \\
\hline Productivity & 3.48 & 0.787 & Good \\
\hline Safety & 3.48 & 0.746 & Good \\
\hline Employee performance variable & $\mathbf{3 . 4 9}$ & $\mathbf{0 . 7 0 5}$ & Good \\
\hline
\end{tabular}

Source: research data analyzed

Analysis of the influence of organizational culture on employee performance based on path analysis was explained in the following figure:

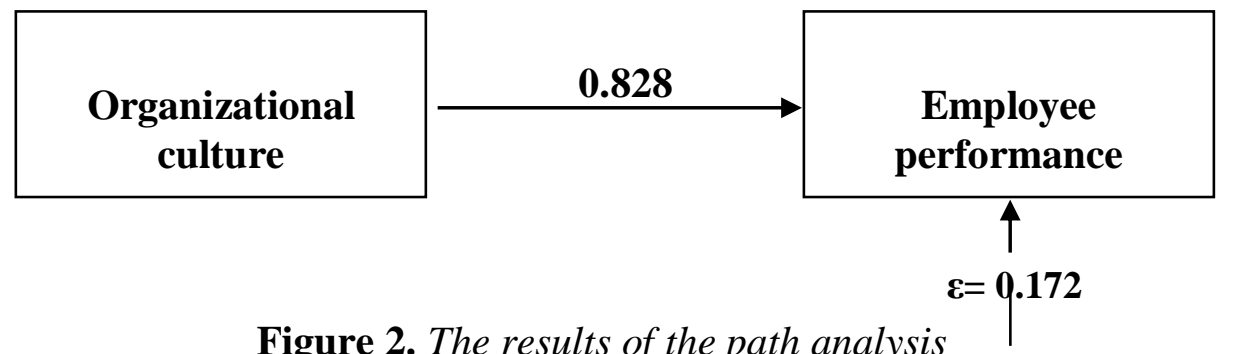

Source: research data analyzed

The results of the regression test analysis using the SPSS 19 program can be seen in the following table:

Table 3. Regression Coefficients

Coefficients $^{\text {a }}$

\begin{tabular}{|c|c|c|c|c|c|c|}
\hline & & \multicolumn{2}{|c|}{$\begin{array}{c}\text { Unstandardized } \\
\text { Coefficients }\end{array}$} & $\begin{array}{c}\text { Standardized } \\
\text { Coefficients }\end{array}$ & \multirow[b]{2}{*}{$\mathrm{t}$} & \multirow[b]{2}{*}{ Sig. } \\
\hline \multicolumn{2}{|c|}{ Model } & $\mathrm{B}$ & Std. Error & Beta & & \\
\hline 1 & (Constant) & -1.929 & 2.820 & & -.684 & \\
\hline & $\begin{array}{l}\text { Organizational_Cult } \\
\text { ure }\end{array}$ & .788 & .050 & .828 & 15.683 & .00 \\
\hline
\end{tabular}

a. Dependent Variable: Employee_Performance

Source: research data analyzed

The table above showed that the correlation coefficient of organizational culture on employee performance was 0.828 . This means that organizational culture had an influence of $68.5 \%$ on employee performance. The remaining score of the influence of organizational culture on employee performance was $31.5 \%$ caused by external factors not included in the research object. Based on the data processing and analysis above, the influence of organizational culture $(\mathrm{X})$ on employee performance $(\mathrm{Y})$ had to be tested statistically using the following statistical hypotheses:

$$
\begin{array}{ll}
\mathrm{H}_{0}: \rho_{\mathrm{xy}}=0 & \begin{array}{l}
: \text { There is no influence of organizational culture on employee } \\
\text { performance }
\end{array} \\
\mathrm{H}_{1}: \rho_{\mathrm{xy}} \neq 0 & \begin{array}{l}
: \text { There is an influence of organizational culture on employee } \\
\text { performance }
\end{array}
\end{array}
$$


Table 4. Testing organizational culture $(\mathrm{X})$ on employee performance (Y)

\begin{tabular}{|c|c|c|c|c|c|}
\hline Structural & $\begin{array}{c}\text { Correlation } \\
\text { coefficient }\end{array}$ & t-count & t-table & P-value & Conclusion \\
\hline$\rho \mathrm{XY}$ & 0.828 & 15.683 & 1.661 & 0.000 & $\begin{array}{l}\mathrm{H}_{0} \text { is rejected. } \mathrm{H}_{1} \text { is } \\
\text { accepted. There is a } \\
\text { significant influence } \\
\text { between } \mathrm{X} \text { and Y }\end{array}$ \\
\hline
\end{tabular}

Source: research data analyzed

For the correlation coefficient of $\rho \mathrm{XY}=0.828$, a $\mathrm{t}_{\text {count }}$ of 15.683 was obtained by taking $\alpha$ significant level of 5\%. Thus, $t_{\text {he table }}$ was 1.661. Since $t_{\text {count }}=15.683$ was greater than $\mathrm{t}_{\text {table }}=1.661, \mathrm{H}_{0}$ was rejected and was accepted. In other words, there was a significant influence between culture organizations $(\mathrm{X})$ on employee performance $(\mathrm{Y})$. The results of this study were divided into two parts, namely descriptive and verification discussion. The descriptive discussion was assessed based on the results of the analysis using the average values, standard deviations, and range of scores. Meanwhile, the verification discussion was examined based on the results of path analysis and hypothesis testing.

The results of the analysis prove that organizational culture had an average score of 3.45. Thus, organizational culture can be categorized as good. This implies that organizational culture had a very important role in improving employee performance in the $P D A M$ office in Majalengka Regency. Therefore, the implementation of service activities to the community was achieved well based on the innovation and risk placement, peopleorientation, team orientation, and aggressiveness dimensions. However, other dimensions had not been fully implemented by the Director of $P D A M$ in Majalengka Regency. Those dimensions obtained a quite good category. They were attention to task details, outcome orientation, and stability dimensions. Hence, there needs to be an effort from the director to further maximize the application of organizational culture in the PDAM office in Majalengka Regency to improve employee performance. The results of the analysis prove that the average score of service quality was 3.49 which indicated that the employee performance was in a good category. This implies that the employee performance at the PDAM office in Majalengka Regency was considered to be good and by employee performance standards set based on effectiveness, efficiency, productivity, and safety dimensions. Although those dimensions were categorized as good, two dimensions only obtained a quite good category, namely quality and timeliness dimensions. This proves that the performance of employees at the Majalengka Regency PDAM office was not yet optimal. Thus, a good organizational culture needs to be applied to improve employee performance. The organizational culture had a positive and significant influence on employee performance. This study has proved empirically that the role of organizational culture is an important factor in both government and private organizations, especially in shaping employee behavior that has an impact on improving employee performance. This finding was supported by a previous study conducted by Tianya and Wardani (Tianya LI 2015; Wardani 2016) which proved that organizational culture has an impact on changing the behavior of employee performance. Empirical organizational culture does not only influence the performance of the individual employee, but it also contributes to forming organizational commitment (Joko Suwaryo, Heny K. Daryanto 2015) in shaping organizational performance (Joko Suwaryo, Heny K. Daryanto 2015). 


\section{IV.Conclusion}

The organizational culture had been well implemented by the Director, as evidenced by obtaining an average score of 3.45 and a standard deviation of 0.574 with a good predicate. However, the application of the employee accuracy and outcome orientation was not optimal and lacks in creating challenges and a system of working conditions. Whereas, employee performance at the PDAM office in Majalengka Regency had been well achieved. That statement was supported by obtaining an average score of 3.49 and a standard deviation of 0.705 with a good predicate. However, the work quality and accuracy in work had not been maximized yet. Based on the results of hypothesis testing, the organizational culture had a positive and significant effect on employee performance. This was evidenced by a correlation coefficient of 0.828 and a significant level of 15.683. This indicates that the t-count was greater than the t-table. Therefore, $\mathrm{H}_{0}$ was rejected and $\mathrm{H}_{1}$ was accepted. In other words, there was a positive and significant influence between organizational cultures on employee performance.

Based on the conclusion above, it implies that the organizational culture variable has a positive and significant influence on employee performance at the PDAM office in Majalengka Regency. Therefore, PDAM Director should pay more attention to the employees' accuracy in carrying out the work and routine meetings to evaluate and maximize the performance of employee work to achieve the expected goals. The director can also create work challenges by giving rewards to employee who carry out their work well, increase the number of outreach activities regarding services procedures and requirements needed to the community, give a reprimand to employees who provide services not following the provisions, and provide direction and guidance to employee to implement the service can run according to a predetermined time.

\section{REFERENCES}

Ahmed, Mashal, and Saima Shafiq. 2014. "The Impact of Organizational Culture on Organizational Performance :" Global Journal of Management and Business Research: A Administration and Management 14(3).

Ehtesham, Ul Mujeeb, Tahir Masood Muhammad, and Shakil Ahmad Muhammad. 2011. "Relationship between Organizational Culture and Performance Management Practices : A Case of University in Pakistan." Journal of Competitiveness (4): 78-86.

Faizal, Mohd, and Mohd Isa. 2016. "The Influence of Organizational Culture on Employees' Performance: Evidence from Oman The Influence of Organizational Culture on Employees ' Performance: Evidence from Oman." Journal of Entrepreneurship and Business (December).

Joko Suwaryo, Heny K. Daryanto, Agus Maulana. 2015. "Organizational Culture Change and Its Effect on Change Readiness through Organizational Commitment." International Journal of Administrative Science \& Organization 22(1).

My, Dang Van, Nguyen Thi, and Thuy Hanh. 2020. "Evaluating Satisfaction of Citizens on Quality of Public Administration Services in the Central Highlands of Vietnam." 6(225): 308-14.

Nanda Novziransyah. 2017. "Pengaruh Budaya Organisasi Terhadap Kinerja Karyawan PT. PLN (Persero) Kantor Wilayah Sumatera Utara Medan.” Jurnal Jumantik 2(1): 13-25.

Sagita, Alinvia Ayu. 2018. "Pengaruh Budaya Organisasi Terhadap Kinerja Karyawan Dengan Motivasi Kerja Sebagai Variabel Mediator (Studi Pada PT Astra Internasional, 
Tbk-Toyota (Auto2000) Cabang Sutoyo Malang).” Jurnal Administrasi Bisnis (JAB) 57(1): 73-82.

Tianya LI. 2015. "Organizational Culture \& Employee Behavior." Lahti University of Applied Sciences.

Ting, Keng-sheng. 2011. "Research on the Influence of Organizational Culture and Organizational Restructuring on Organizational Performance: Taking Old Folks Nursing Organization in Taiwan as an Example." The Journal of Human Resource and Adult Learning 7(December): 96-109.

Wardani, Rodiathul Kusuma. 2016. "Pengaruh Budaya Organisasi Terhadap Kinerja Karyawan (Studi Pada Karyawan PT Karya Indah Buana Surabaya)." Jurnal Administrasi Bisnis (JAB) 31(1): 58-65.

Yadav, Manish Kumar, and Alok Kumar Rai. 2015. "Exploring the Relational Impact of Service Quality on Customer Satisfaction.” 4: 17-31. 